\title{
RESEARCH
}

Open Access

\section{Immediate and legacy effects of snow exclusion on soil fungal diversity and community composition}

\author{
Li Zhang ${ }^{1 \dagger}$, Yuzhi Ren ${ }^{1 \dagger}$, Kaijun Yang ${ }^{2}$, Zhijie Li ${ }^{3}$, Bo Tan', Yang Liu', Han Li', Chengming You', Sining Liu',
} Lixia Wang ${ }^{1}$, Rui Yinn ${ }^{4}$, Jian Zhang ${ }^{1}$ and Zhenfeng $X^{1{ }^{*}}$ (D)

\begin{abstract}
Background: Soil fungi play crucial roles in ecosystem functions. However, how snow cover change associated with winter warming affects soil fungal communities remains unclear in the Tibetan forest.

Methods: We conducted a snow manipulation experiment to explore immediate and legacy effects of snow exclusion on soil fungal community diversity and composition in a spruce forest on the eastern Tibetan Plateau. Soil fungal communities were performed by the high throughput sequencing of gene-fragments.

Results: Ascomycota and Basidiomycota were the two dominant fungal phyla and Archaeorhizomyces, Aspergillus and Amanita were the three most common genera across seasons and snow manipulations. Snow exclusion did not affect the diversity and structure of soil fungal community in both snow-covered and snow-free seasons. However, the relative abundance of some fungal communities was different among seasons. Soil fungal groups were correlated with environmental factors (i.e., temperature and moisture) and soil biochemical variables (i.e., ammonium and enzyme).
\end{abstract}

Conclusions: These results suggest that the season-driven variations had stronger impacts on soil fungal community than short-term snow cover change. Such findings may have important implications for soil microbial processes in Tibetan forests experiencing significant decreases in snowfall.

Keywords: Winter climate change, Snow cover, Fungi, Community diversity, Community composition, Illumina sequencing

\footnotetext{
* Correspondence: xuzf@sicau.edu.cn

${ }^{+}$Li Zhang and Yuzhi Ren contributed equally to this work.

${ }^{1}$ Forestry Ecological Engineering in the Upper Reaches of the Yangtze River

Key Laboratory of Sichuan Province \& National Forestry and Grassland

Administration Key Laboratory of Forest Resources Conservation and

Ecological Safety on the Upper Reaches of the Yangtze River \& Rainy Area of

West China Plantation Ecosystem Permanent Scientific Research Base,

Institute of Ecology \& Forestry, Sichuan Agricultural University, Chengdu

611130, China

Full list of author information is available at the end of the article
}

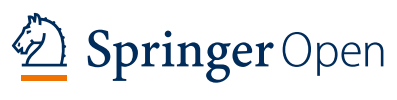

(c) The Author(s). 2021 Open Access This article is licensed under a Creative Commons Attribution 4.0 International License, which permits use, sharing, adaptation, distribution and reproduction in any medium or format, as long as you give appropriate credit to the original author(s) and the source, provide a link to the Creative Commons licence, and indicate if changes were made. The images or other third party material in this article are included in the article's Creative Commons licence, unless indicated otherwise in a credit line to the material. If material is not included in the article's Creative Commons licence and your intended use is not permitted by statutory regulation or exceeds the permitted use, you will need to obtain permission directly from the copyright holder. To view a copy of this licence, visit http://creativecommons.org/licenses/by/4.0/. 


\section{Background}

Seasonal snow cover is one of the most important factors that drive biogeochemical cycling in cold regions (Jusselme et al. 2016; Liu et al. 2018). Winter warming is predicted to reduce the stability and thickness of snow cover in snowy regions (Gobiet et al. 2014). The decline or absence of insulation of the snow cover would alter soil environmental conditions (e.g., temperature, moisture, frost intensity and duration) during winter and the growing season (Wipf and Rixen 2010; Kreyling et al. 2012; Aanderud et al. 2013; Li et al. 2017; Song et al. 2017). Soil environmental conditions are very important to mediate soil microbial community in cold ecosystems (Zinger et al. 2009; Voř́š́sová et al. 2014; Morgado et al. 2016). Hence, reduced snow cover associated with winter climate change can result in more intensive soil freezing, which may in turn have profound influences on soil biological processes, especially soil fungal communities.

Soil fungi are the key decomposer of soil organic matter in cold soils (Baldrian 2017). The diversity and composition of fungal communities play key roles in soil carbon and nutrient cycling (Cheng et al. 2017; Asemaninejad et al. 2018). Therefore, it is crucial to understand how fungal community responds to snow cover change in alpine soils. Some studies have shown that snow depth change resulted in an immediate effect on soil fungal community composition in snow-covered winter (Olofsson et al. 2011; Barbeito et al. 2013; Voř́íšková et al. 2014; Santalahti et al. 2016). However, winter snowpack can affect the soil moisture and nutrients in the subsequent growing season (Wipf and Rixen 2010). Therefore, snow cover change could also lead to carryover effects on soil fungal community composition in snow-free growing season (Buckeridge et al. 2013; Wubs et al. 2018; Sorensen et al. 2020). To our knowledge, soil fungal responses to altered snow cover have scarcely been investigated both in snow-covered winter and snow-free growing season. Obviously, exploring the immediate and legacy effects of snow cover change on fungal community is very essential to understand microbe-associated ecological processes in cold soils.

As the earth's 'Third Pole', the Tibetan Plateau is anticipated to become warmer in the coming decades (Chen et al. 2013). In this region, winter snowfall has been decreasing over last decades (Wang et al. 2016; Deng et al. 2017). Winter soil temperature is close to the physical melting point and is sensitive to snow cover change (Wang et al. 2007; Li et al. 2017). Our prior study has found that snow exclusion reduced soil respiration and enzyme activities in wintertime, but did not result in any cross-seasonal effects in subsequent snowfree season (Yang et al. 2019). Fungal communities are considered as key agents controlling soil $\mathrm{C}$ cycling in cold ecosystems (Clemmensen et al. 2013; Zhang et al.
2013; Solly et al. 2017). In this study, we aimed to evaluate the immediate and legacy effects of snow exclusion on the diversity and composition of soil fungal communities. Specifically, we hypothesized that, snow exclusion (1) will decline soil fungal communities, and thereby change fungal community composition; (2) will result in both immediate and carry-over impacts on soil fungal communities; (3) will affect fungal communities via changes in environmental and/or soil biochemical factors.

\section{Methods \\ Site description}

The study was conducted in a dragon spruce (Picea asperata) stand at the Long-term Research Station of Alpine Forest Ecosystems of Sichuan Agricultural University, which is located at the eastern Tibetan Plateau of China ( $31^{\circ} 15^{\prime} \mathrm{N}, 102^{\circ} 53^{\prime} \mathrm{E}$; $3021 \mathrm{~m}$ a.s.l.). The mean annual temperature is $3.0^{\circ} \mathrm{C}$, with maximum and minimum temperatures of $23.0^{\circ} \mathrm{C}$ (July) and $-18.0{ }^{\circ} \mathrm{C}$ (January), respectively. Annual precipitation is about $850 \mathrm{~mm}$. In general, snow begins to accumulate in late November and melts in late March of the following year. The understory is dominated by Salix paraplesia, Rhododendron lapponicum, Cacalia sp., Carex sp., and Cyperus sp. (Li et al. 2017). The soil is classified as Cambic Umbrisols (IUSS Working Group WRB 2007).

\section{Experimental design}

Winter snowfall was excluded using shelters. This technique can effectively reduce snow cover and minimize unwanted environmental conditions ( $\mathrm{Li}$ et al. 2017). In early November 2015, six wooden roofs ( $2 \mathrm{~m}$ height, 3 $\mathrm{m} \times 3 \mathrm{~m}$ ground area) were established in the Picea asperata forest to prevent snow accumulation on the ground. One control plot that allows snow input was set up in the vicinity of each wooden roof $(3 \mathrm{~m} \times 3 \mathrm{~m}$ ground area). In late winter, the accumulated snow on the roof was added to the forest floor in order to ensure the similar water balance between the snow-free and control plots. The snow manipulation began in late November 2015 and ended in early April 2016 when the seasonal snow in the control plots was melted (Li et al. 2017).

\section{Microclimate and soil biochemical analyses}

Soil temperature $(5 \mathrm{~cm}$ depth) and air temperature $(2 \mathrm{~m}$ height) were measured every $1 \mathrm{~h}$ by the Thermochron iButton DS1923-F5 Recorders (Maxim Dallas Semiconductor Corp., USA). The minimum daily mean soil temperatures of the control and snow exclusion plots were $-0.5{ }^{\circ} \mathrm{C}$ and $-2.2{ }^{\circ} \mathrm{C}$, respectively (Fig. S1). The snow exclusion increased winter soil frost and lowered the average soil temperature (Fig. S1a). Seasonal snow began to accumulate in late November 2015 and melted 
in early April 2016 (Fig. S1). Snow depth in the control plots was measured approximately every 2 weeks. There was no obvious difference in soil moisture between control and snow exclusion plots (Fig. S1b).

Soil $\mathrm{pH}$ was determined on field moist soil in a 1:2.5 $(\mathrm{M} / \mathrm{V})$ soil suspension using a $\mathrm{pH}$ meter (PHS-25CW, BANTE Instruments Limited, Shanghai, China). Soil ammonium $\left(\mathrm{NH}_{4}^{+}-\mathrm{N}\right)$ and nitrate $\left(\mathrm{NO}_{3}^{-}-\mathrm{N}\right)$ were extracted with $2 \mathrm{~mol} \cdot \mathrm{L}^{-1} \mathrm{KCl}$, and then $\mathrm{NH}_{4}^{+}$and $\mathrm{NO}_{3}^{-}$ in the extracts was determined using colorimetry (Xu et al. 2010). Soil microbial biomass carbon (MBC) was measured by the fumigation-extraction method (Vance et al. 1987). The released $C$ was converted to MBC using kec 0.45 (Vance et al. 1987).

We assessed the activities of three enzymes involved in soil $\mathrm{C}, \mathrm{N}$ and $\mathrm{P}$ cycling: $1,4-\beta$-glucosidase (BG), $\beta-\mathrm{N}$ acetyl-glucosaminidase (NAG) and acid phosphatase (AP). The activities were assayed using the methods described by Allison and Jastrow (2006). Substrate solutions were 5 $\mathrm{mmol} \cdot \mathrm{L}^{-1} \mathrm{pNP}-\beta$-glucopyranoside for $\mathrm{BG}, 2 \mathrm{mmol} \cdot \mathrm{L}^{-1}$ pNP- $\beta$-N-acetylglucosaminide for NAG and $5 \mathrm{mmol} \cdot \mathrm{L}^{-1}$ pNP-phosphate for AP. Activities was measured using a microplate spectrophotometer and expressed as $\mu \mathrm{mol}$ of substrate produced or consumed $\mathrm{h}^{-1} \cdot \mathrm{g}^{-1}$ dry soil.

\section{Soil sampling}

In 2016, three snow exclusion plots and their corresponding controls were randomly selected. Soil samples were collected from the topsoil $(0-15 \mathrm{~cm})$ in mid-February (deep snow period, DSP), early April (early thawing period, ETP), and mid-August (middle of the growing season, MGS), respectively. On each sampling date, three soil cores $(5 \mathrm{~cm}$ in diameter, $0-15 \mathrm{~cm}$ deep) were randomly taken at each plot and were mixed into one composite sample per plot. The composite sample was passed through a 2-mm sieve, and any visible living plant material was removed from the sieved soil. Subsamples of the sieved soils were stored in the refrigerator at $-70^{\circ} \mathrm{C}$ and $4{ }^{\circ} \mathrm{C}$, respectively, for DNA and routine chemical analyses.

\section{DNA extraction, PCR amplification and Illumina MiSeq sequencing}

Microbial DNA was extracted from 18 soil samples by using the E.Z.N.A. Soil DNA Kit (Omega Bio Inc. Norcross, GA, USA) according to manufacturer's protocols. The final DNA concentration and purification were determined by Nanodrop ${ }^{\circ}$ ND-1000 UV-Vis spectrophotometer (Nano-Drop Technologies, Wilmington, DE, USA), and DNA quality was checked by $1 \%$ agarose gel electrophoresis.

The fungal 18S rDNA gene was amplified with the primers SSU0817F/SSU1196R (Borneman and Hartin
2000) by a thermocycler PCR system (GeneAmp 9700, $\mathrm{ABI}$, USA). PCR reactions were performed in triplicate using a $20 \mu \mathrm{L}$ mixture containing $4 \mu \mathrm{L}$ of $5 \times$ FastPfu Buffer, $2 \mu \mathrm{L}$ of $2.5 \mathrm{mmol} \cdot \mathrm{L}^{-1}$ dNTPs, $0.8 \mu \mathrm{L}$ of each primer $\left(5 \mu \mathrm{mol} \cdot \mathrm{L}^{-1}\right), 0.4 \mu \mathrm{L}$ of FastPfu Polymerase and $10 \mathrm{ng}$ of template DNA. The PCR reactions were conducted using the following program: denaturation at $95^{\circ} \mathrm{C}$ for $3 \mathrm{~min}$, annealing at $55^{\circ} \mathrm{C}$ for $30 \mathrm{~s}$, and elongation at $72{ }^{\circ} \mathrm{C}$ for $45 \mathrm{~s}$, and a final extension at $72{ }^{\circ} \mathrm{C}$ for $10 \mathrm{~min}$. The step from the denaturation to extension was run for 35 cycles.

The resulted PCR products were extracted from a $2 \%$ agarose gel and further purified using the AxyPrep DNA Gel Extraction Kit (Axygen Biosciences, Union City, CA, USA) and quantified using QuantiFluor ${ }^{\mathrm{rm}}-\mathrm{ST}$ (Promega, USA) according to the manufacturer's protocol. The purified amplicons were pooled in equimolar and paired-end sequenced $(2 \times 300)$ on an Illumina MiSeq platform (Illumina, San Diego, USA) according to the standard protocols by Majorbio Bio-Pharm Technology Co. Ltd. (Shanghai, China). The raw reads were deposited in the NCBI Sequence Read Archive (SRA) database with accession number PRJNA562976.

\section{Processing of sequencing data}

Raw FASTQ files were demultiplexed and qualityfiltered by Trimmomatic and merged by FLASH with the following criteria: (i) the reads were truncated at any site receiving an average quality score $<20$ over a 50 -bp sliding window; (ii) Primers were exactly matched allowing two-nucleotide mismatching, and reads containing ambiguous bases were removed; (iii) Sequences whose overlap was longer than $10 \mathrm{bp}$ were merged according to their overlap sequence.

All sequences acquired using the Illumina-MiSeq was saved in the raw fastq files. Initial processing of the raw dataset included screening to remove short and lowquality reads; only high-quality sequences were retained. Operational taxonomic units (OTUs) were clustered with 97\% similarity cutoff using UPARSE (version 7.1, http:// drive5.com/uparse/), and chimeric sequences were identified and removed using UCHIME (Edgar et al. 2011). The taxonomy of each $18 \mathrm{~S}$ rDNA gene sequence was analyzed by the RDP Classifier algorithm (http://rdp.cme.msu.edu/) against the Silva 128/18S_eukaryota database using a confidence threshold of $70 \%$. Rarefaction curves and alpha diversity calculations were based on OTUs with $>97 \%$ identity. Rarefaction analysis and alpha-diversity indices (abundance-based Sobs, Chao1, Shannon and Simpson) were revealed by Mothur (Schloss et al. 2009).

\section{Statistical analysis}

Alpha diversity metrics, including the Shannon-Wiener index, Simpson's diversity index, richness (Sobs) and 
community coverage, were calculated to determine the "diversity" and "richness" functions of the fungal community. Repeated measures ANOVAs were performed to test the effects of treatment, sampling date (deep snow period, early thawing period, middle of the growing season), and their interactions on the fungal indices. For specific sampling dates, Student $t$-tests were used to compare the effect of snow exclusion. The statistical tests were considered significant at the $P<0.05$ level. All statistical analyses were performed using SPSS 20.0 (IBM Corporation, Armonk, NY, USA).

One-way ANOVA with Tukey-kramer post hoc tests were performed to test the effects of sampling date on the abundance of fungal community at the same treatment. For individual sampling dates, Wilcoxon ranksum test was used to compare the effect of snow exclusion on the abundance of fungal community structure. Statistical testing among variation in fungal community composition was carried out using the analysis of similarity (ANOSIM). Differences in soil fungal phyla were represented on a two-dimensional ordination plot following Non-metric multidimensional scaling (NMDS) analysis based on Bray-Curtis distance. Spearman correlation heatmap analysis was performed to examine the relationships between the relative abundance of fungal taxa and environmental factors or biochemical properties. All statistical analyses were performed using the VEGAN package of the R software (Oksanen et al. 2013; R Development Core Team 2015).

\section{Results}

\section{Pyrosequence data description and species alpha diversity}

Pyrosequencing of 18 samples had a total of 604,373 raw sequences. A total of 215,046 sequences were retained after quality control. The sequence data were classified into 167 OTUs at $97 \%$ similarity. After normalization, each library had 11,947 reads and the sequence was clustered into 70-137 OTUs (Table S1). All rarefaction curves tended to approach the saturation plateau, indicating that the data volume of sequenced reads was reasonable (Fig. 1a). In the deep snow period, the Shannon index was higher compared to the early thawing period and the middle of the growing season (Fig. 1b). However, the Shannon and Simpson indices were unaffected by snow exclusion (Fig. 1b).

\section{Taxonomic composition of fungal}

The OTUs were classified into 8 fungal phyla, 43 orders, 59 families and 60 genera (Fig. 2 and Table S2). The first three rich OTUs were Ascomycota (35.93\%), Basidiomycota (19.76\%) and Chytridiomycota (16.17\%), respectively. Other fungal groups, including Glomeromycota, LKM 15 and Cryptomycota together comprised the $12.58 \%$ of
OTUs (Table S2). Unclassified and norank sequences represented $15.57 \%$ of OTUs.

Ascomycota were distributed across 18 orders and dominated by Hypocreales (15.28\% of all sequences), Archaeorhizomycetales (8.55\%) and Eurotiales (4.72\%). Basidiomycota were distributed across 7 orders and dominated by Agraicales (4.10\%), Tremellales (1.36\%) and Russulales (0.25\%) (Table S2).

At the genus level, 14 genera belonged to Ascomycota and 3 genera belonged to Basidiomycota (Table 1). The most abundant genus (Saprotroph Archaeorhizomyces) accounted for $8.55 \%$ of all sequences, followed by saprotroph Aspergillus (4.49\%) and ectomycorrhiza Amanita (2.89\%) (Table 1).

\section{Variation in fungal community composition}

Across all sites, fungal communities were consistently dominated by Ascomycota $(38.3 \%-55.6 \%)$ and Basidiomycota $(7.92 \%-54.50 \%)$ (Fig. 2a). The relative abundance of the Chytridiomycota $(0.81 \%-18.1 \%)$, Glomeromycota (0.33\%-1.18\%), LKM15 (0.05\%-0.84\%) and Cryptomycota $(0.01 \%-0.19 \%)$ was very low in all samples. Based on Bray-Curtis, ANOSIM and NMDS were used to compare the similarity of the fungal phyla between treatments or seasons (Fig. 3). There were significant differences in soil fungal communities among seasons. Soil fungal community in the middle of the growing season was obviously different from that in the deep snow period and early thawing period (Fig. 3; ANOSIM, $r=0.527, P=0.001)$. In the control plots, Basidiomycota was much higher in the middle of the growing season than in the deep snow period $(P<0.05)$ (Fig. S2). In the treatment plots, LKM15 in the deep snow period was much higher than that in the middle of the growing season $(P<0.05)$ (Fig. S2). However, no significant differences were found between snow regimes (Figs. 3 and S3; ANOSIM, $r=-0.031, P=0.539$ ).

At the genus level, 17 distinct groups were observed in all samples which belonged to 12 classes (Fig. 2b, Table 1). Archaeorhizomyces (Archaeorhizomycetes), Aspergillus (Eurotiomycetes) and Amanita (Agaricomycetes) were the first three abundant genera (Fig. 2b, Table 1). Snow exclusion did not show any significant effects on the abundance of each genus, while sampling period had significant effect (Figs. S4 and S5).

\section{Correlation between soil biochemical properties and fungal communities}

Spearman correlation heatmap analysis was performed to examine the relationships between the phylum and genus level of fungal communities and soil environmental and biochemical variables (Fig. 4). For the known phyla, soil temperature, $\mathrm{NH}_{4}^{+}-\mathrm{N}$ and enzyme activities 

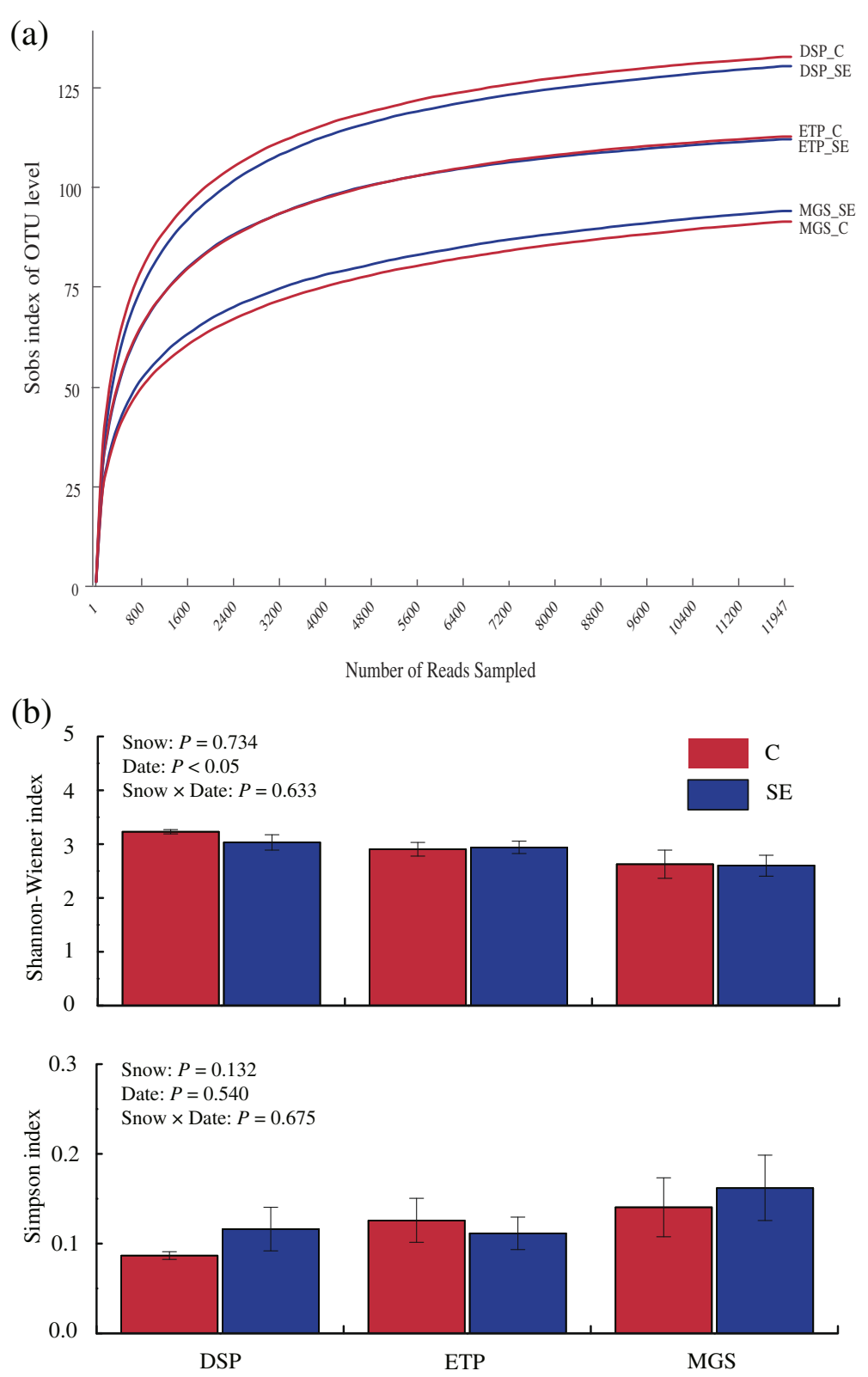

Fig. 1 Rarefaction curve of the OTU number at 97\% similarity cutoff (a) and a diversity index (b) of soil fungal community in control (C) and snow exclusion (SE) plots in the deep snow period (DSP), early thawing period (ETP), and in the middle of the growing season (MGS). * indicated a significant difference between control and snow exclusion on a specific same sampling date. Data shown are mean \pm s.e

(BG, AP and NAG) were important influence factors (Fig. 4a). For the three common genera, a negative correlation was observed between Aspergillus and $\mathrm{NO}_{3}^{-}-\mathrm{N}$. Moreover, Amanita showed significant correlations with $\mathrm{pH}, \mathrm{NH}_{4}^{+}-\mathrm{N}, \mathrm{BG}$ and $\mathrm{AP}$ activities (Fig. 4b).

\section{Discussion}

The depth and duration of winter snow have been decreasing on the eastern Tibetan Plateau (Li et al. 2017). Recent studies have reported that snow cover change caused significant effects on soil fungal communities in arctic cold ecosystems (Morgado et al. 2016; Semenova et al. 2016). We utilized a snow-exclusion experiment to test the immediate and cross-seasonal effect of snow exclusion on the diversity and composition of soil fungal communities in a subslpine spruce forest on the eastern Tibetan Plateau. Inconsistent with our hypotheses, snow exclusion did not affect the diversity and composition of soil fungal communities in both snow-covered winter and snow-free growing season, but the fungal diversity and composition greatly varied across seasons, indicating 

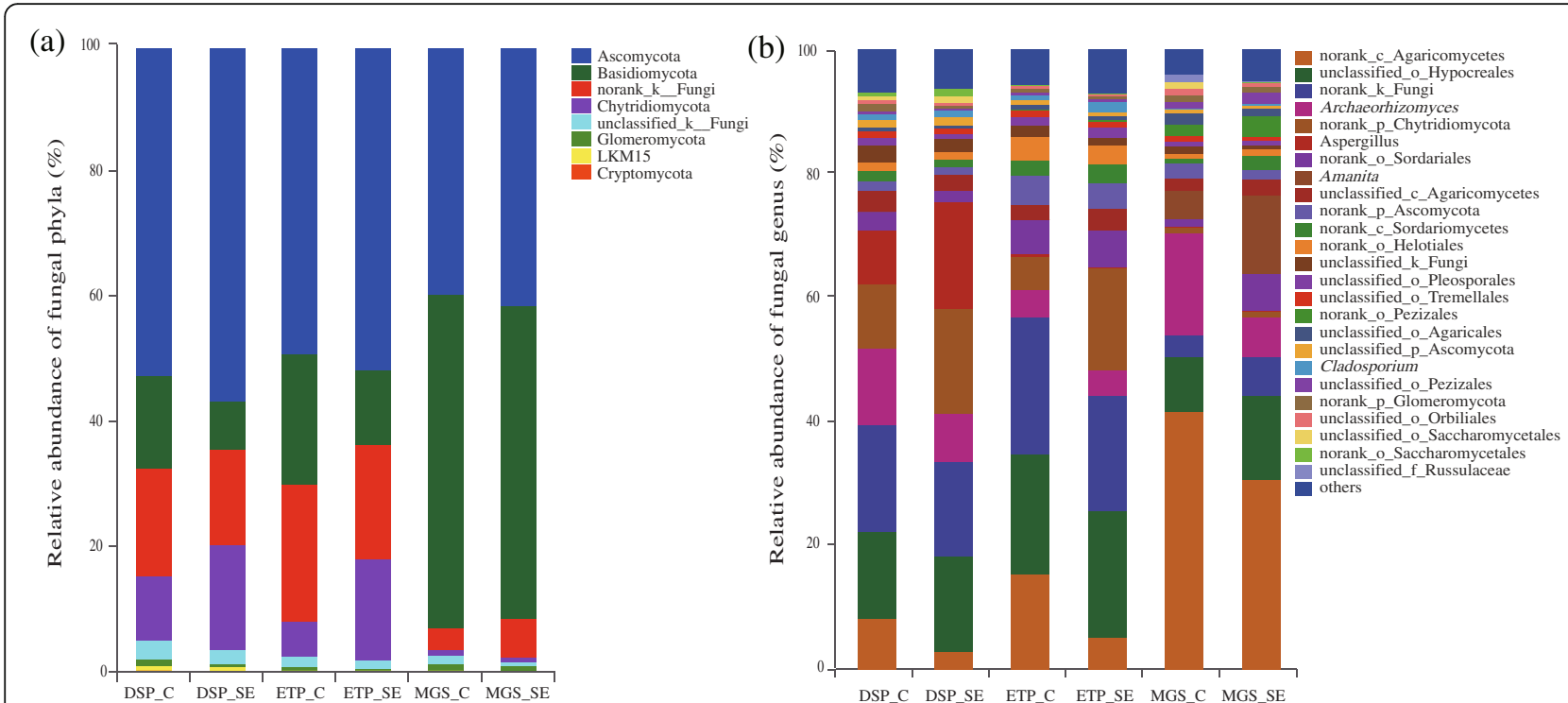

Fig. 2 Relative abundance of different fungal phyla (a) and genus (b) in control (C) and snow exclusion (SE) plots in the deep snow period (DSP), early thawing period (ETP), and in the middle of the growing season (MGS)

that soil fungal communities were not sensitive to shortterm mild increased frost associated with snow cover absence.

Both phylum Ascomycota and Basidiomycota were the two dominant phyla in the study site. Similar findings are observed in other cold ecosystems, such as glacier ecosystems, alpine meadows and boreal forests (Yao et al. 2013; Antony et al. 2016; Gao and Yang 2016;
Chen et al. 2017a, 2017b; Han et al. 2017; Männistö et al. 2018). Hypocreales, Archaeorhizomycetales and Eurotiales were the dominant orders in the phylum Ascomycota. In addition, Agaricales was the dominant order in the phylum Basidiomycota. As stated above, there might be similar common soil fungal communities among different snowy environments, indicating these fungal communities have an extensive adaptability.

Table 1 List of the genera after OTU assignment. Functional group, total and relative number of sequences and OTUs are given for each genus from the total dataset

\begin{tabular}{|c|c|c|c|c|c|c|c|}
\hline Phylum & Classes & Genus & Functional group & No. of sequences & Percent (\%) & No. of OTUs & Percent (\%) \\
\hline \multirow[t]{14}{*}{ Ascomycota } & Archaeorhizomycetes & Archaeorhizomyces & Saprotroph & 18,397 & 8.55 & 2 & 1.20 \\
\hline & Eurotiomycetes & Aspergillus & Saprotroph & 9666 & 4.49 & 2 & 1.20 \\
\hline & Dothideomycetes & Cladosporium & Saprotroph & 1779 & 0.83 & 1 & 0.60 \\
\hline & Dothideomycetes & Boeremia & & 1316 & 0.61 & 1 & 0.60 \\
\hline & Dothideomycetes & Aureobasidium & Saprotroph & 978 & 0.45 & 1 & 0.60 \\
\hline & Dothideomycetes & Guignardia & Pathogen & 955 & 0.44 & 1 & 0.60 \\
\hline & Pezizomycetes & Tarzetta & Ectomycorrhiza & 800 & 0.37 & 1 & 0.60 \\
\hline & Sordariomycetes & Pseudallescheria & Saprotroph & 670 & 0.31 & 1 & 0.60 \\
\hline & Pezizomycetes & Helvella & Ectomycorrhiza & 188 & 0.09 & 1 & 0.60 \\
\hline & Saccharomycetes & Galactomyces & Saprotroph & 120 & 0.06 & 1 & 0.60 \\
\hline & Saccharomycetes & Pichia & Saprotroph & 97 & 0.05 & 1 & 0.60 \\
\hline & Eurotiomycetes & Arachnomyces & & 49 & 0.02 & 1 & 0.60 \\
\hline & Pezizomycetes & Peziza & Saprotroph & 38 & 0.02 & 1 & 0.60 \\
\hline & Dothideomycetes & Cochliobolus & Pathogen & 15 & 0.01 & 1 & 0.60 \\
\hline \multirow[t]{3}{*}{ Basidiomycota } & Agaricomycetes & Amanita & Ectomycorrhiza & 6223 & 2.89 & 1 & 0.60 \\
\hline & Agaricomycetes & Camarophyllopsis & & 644 & 0.30 & 1 & 0.60 \\
\hline & Tremellomycetes & Cryptococcus & Saprotroph & 113 & 0.05 & 1 & 0.60 \\
\hline
\end{tabular}




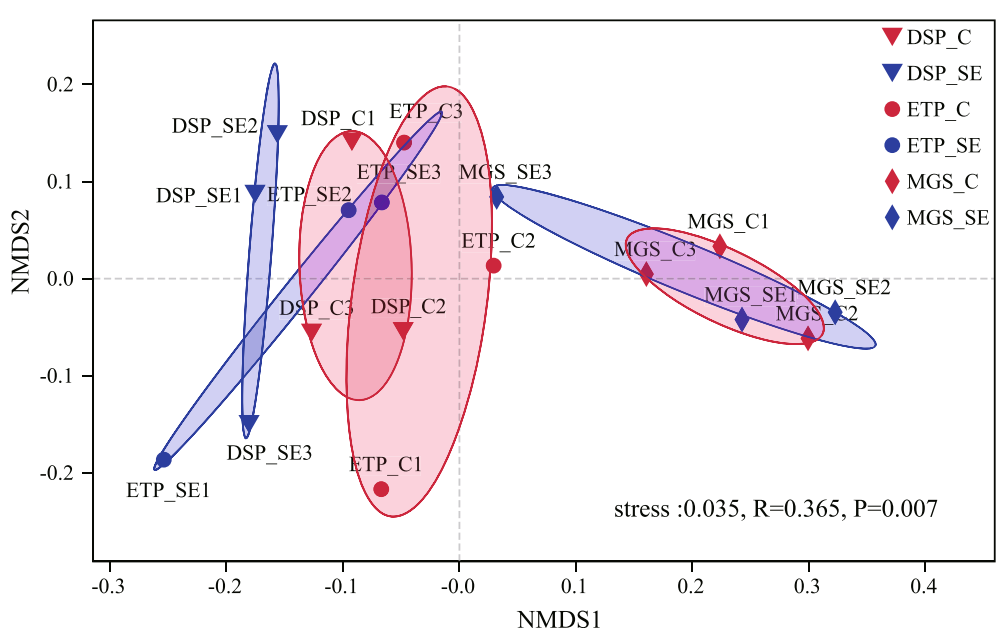

Fig. 3 Non-metric multidimensional scaling (NMDS) plot showing variation in the composition (Bray-Curis distance) of soil fungal communities between snow regimes and sampling periods on phylum level. Different symbols represent different sampling date. The inverted triangle, circle and diamond represents the deep snow period (DSP), early thawing period (ETP) and in the middle of the growing season (MGS), respectively. The hollow represents Control (C) and solid represents snow exclusion (SE) plots

A growing number of studies have revealed that snow cover changes leaded to significant impacts on soil fungal community composition and diversity in cold ecosystems (Mundra et al. 2016; Semenova et al. 2016; Männistö et al. 2018). For example, deeper snow cover decreased saprotrophic fungi but increased ECM fungi richness (Mundra et al. 2016). In addition, increased snow cover significantly altered the composition of soil fungal communities in arctic tundra (Morgado et al.
2016; Semenova et al. 2016). In contrast, the lack of snow cover resulted in slight effects on soil fungal community structure and activity in a boreal coniferous forest (Männistö et al. 2018). Our results are consistent with the observations found in alpine tundra (Zinger et al. 2009) and in temperate and boreal forest ecosystems (Gao et al. 2018), which indicated snow cover change did not affect soil fungal diversity and community composition. This is probably because soil fungal communities in

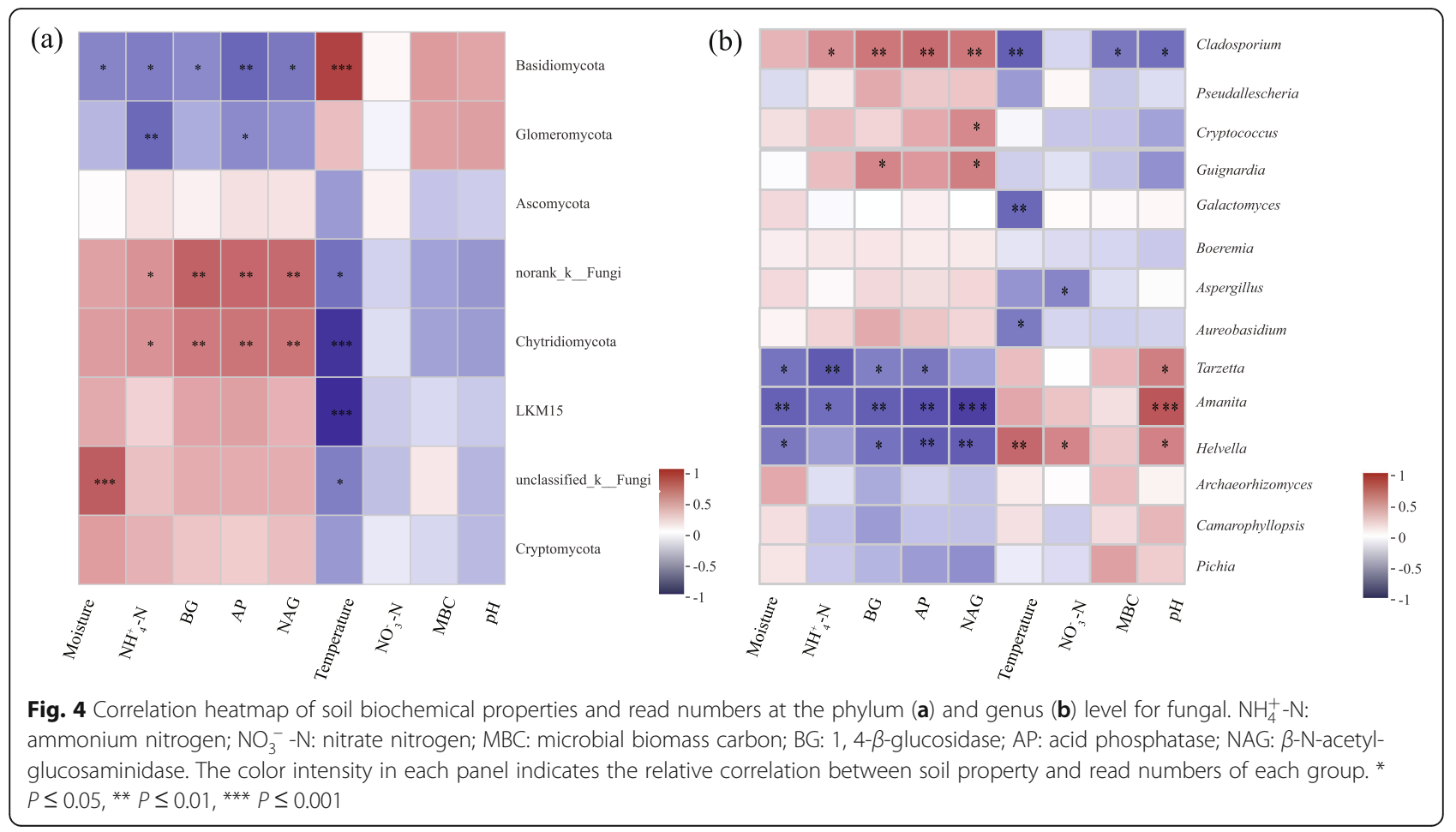


cold regions have developed physiological resistance to extreme conditions, such as low temperature and freezethaw cycles (Stres et al. 2010; Haei et al. 2011). Additionally, fungi can still gain energy through dissolved organic carbon and nitrogen in frozen soils, implying that soil fungal communities had some unique adaptive strategies to survive extreme cold conditions (Fitzhugh et al. 2001; Matzner and Borken 2008; Sorensen et al. 2016). As a result, a short-term mild soil freezing is not powerful enough to alter the diversity and composition of fungal communities in alpine forest soils. On the other hand, snow exclusion did not affect soil fungal communities in the middle of the growing season, implying that the carryover effect of snow exclusion is negligible. This is mainly because no significant differences were detected in both environmental factors (e.g., temperature and moisture) and soil variables (e.g., $\mathrm{N}$ pools, enzyme activities) in this period (Yang et al. 2019).

Although no significant treatment effects were detected, fungal community diversity and composition significantly varied across seasons. This observation is consistent with the results found in boreal forest soils (Voříšková et al. 2014). The Shannon-Wiener index in the deep snow period is higher than those in the early thawing period and in the middle of the growing season, which may be attributed to the low plant cover and diversity in winter (Shi et al. 2014). A study conducted in a Scots pine forest showed that saprotrophs are dominant in winter, but ECM fungi grow rapidly in the growing season (Santalahti et al. 2016). In this study, the Basidiomycota group and genera Amanita (Agaricomycetes) showed a distinct transition from frozen winter to the subsequent growing season. This is mainly because the carbon sources for Basidiomycota are mostly derived from exogenous materials, such as plant litter and wood (Kellner et al. 2010). Therefore, relatively large vegetation coverage and abundance may provide more substrates during the growing season. In addition, relatively rich root exudates can also favor soil fungal community, especially in colder ecosystems (Shahzad et al. 2015; Delgado-Baquerizo et al. 2019). In general, Amanita has a mycorrhizal relationship with vascular plants (Yang 2000). Therefore, plant growth in the growing season may stimulate Amanita growth. At the same time, the warmer temperature in the growing season may also provide suitable conditions for Amanita reproduction and growth (Asemaninejad et al. 2017).

Ascomycota did not vary among seasons in this case, indicating that these fungi having strong resistance and adaptability to environmental stress. Some studies have demonstrated that Ascomycota can adapt to harsh habitats to obtain survival advantages (Chen et al. 2017a; Asemaninejad et al. 2018). However, the genus members of Ascomycota, Archaeorhizomyces and Aspergillus shifted across seasons. The relative abundance of Archaeorhizomyces was found to be highest in the growing season. Studies showed that Archaeorhizomyces, as a group of saprophytic fungi, are dominant in summer (Schadt et al. 2003, Fig. 3) and omnipresent in roots and rhizosphere soil (Rosling et al. 2011). Root-derived compounds are the principal carbon source for these fungi (Rosling et al. 2011). Thus, sufficient high-quality substrates associated with root activity are favorable to Archaeorhizomyces in the growing season (Lindahl et al. 2007). Conversely, the relative abundance of Aspergillus was higher in the deep snow period as compared to the other two periods, which is consistent with the observations in a Pal forest soil (Rane and Gandhe 2006).

Environmental and biochemical variables are two important drivers of microbial community composition (Fitzhugh et al. 2001; Matzner and Borken 2008; Chen et al. 2017b; Asemaninejad et al. 2018). Soil temperature is a key factor affecting fungal communities (Asemaninejad et al. 2017). The abundance of Basidiomycota is relatively high in the warm growing season (Kirk et al. 2001; Asemaninejad et al. 2017). In addition, soil moisture also regulates soil fungal community in forest ecosystems (Bainard et al. 2014; Kim et al. 2016). The significant differences in soil moisture between winter and growing season may, to some extent, account for the separation of fungi group, such as Basidiomycota and Agaricomycetes. Soil enzyme production is mainly derived from soil microbes, especially soil fungi in forest ecosystems (Schneider et al. 2012). Thus, soil enzymes can partially reflect the composition and structure of fungal communities (Frey et al. 2004; Kivlin and Treseder 2014). In our study, soil enzyme activities (e.g., BG, AP, and NAG) showed significant correlations with some specific fungal communities. Similar observations were also found in the California forests ecosystem (Kivlin and Treseder 2014). Soil nutrients, especially nitrogen availability, could affect soil microbial community in cold biomes (Bardgett et al. 2002). Many studies have demonstrated that nitrogen additions alter soil fungal community composition (Pardo et al. 2011; Morrison et al. 2016; Corrales et al. 2017). In this case, seasonal variations in $\mathrm{N}$ pools may partly explain the seasonal dynamic of fungal communities. Previous studies have demonstrated that soil fungal communities have wider $\mathrm{pH}$ ranges for optimal growth (Rousk et al. 2010). Similarly, soil pH was not correlated with fungal communities at the phylum level, suggesting that soil $\mathrm{pH}$ is less important to mediate soil fungal communities in subalpine coniferous forests.

\section{Conclusions}

This study examined the immediate and legacy effects of snow cover change on the diversity and composition of 
fungal communities in a subalpine spruce forest on the Tibetan Plateau of China. Our findings suggested that snow exclusion did not affect soil fungal communities in both snow-covered winter and snow-free growing season, indicating that fungal communities were insensitive to short-term snow cover change in Tibetan forest soils. Besides, soil fungal communities varied across seasons, implying that they had a significant shift when soil transformed from frozen to unfrozen. The season-driven shift in fungal communities may be partly explained by season-related changes in environmental factors (e.g., temperature and moisture) and biochemical variables (e.g., soil $\mathrm{N}$ availability and enzyme activity). Based on our findings, the intensified and extended soil frost associated with winter climate change might profoundly alter the phenology of soil fungal community in subalpine forests experiencing significant snowfall decrease.

\section{Supplementary Information}

The online version contains supplementary material available at https:/doi. org/10.1186/s40663-021-00299-8

Additional file 1: Figure S1. Seasonal dynamics of air temperature (a) ( $2 \mathrm{~m}$ above the ground surface) and soil temperature $(5 \mathrm{~cm}$ depth) from November 2015 to November 2016 and soil moisture (b) in control and snow exclusion plots. The dot indicates snow depth during the winter. The asterisk indicates the sampling period. The small chart shows air and soil temperatures in winter. Figure S2. One-way ANOVA test bar plot for fungal phyla in (a) control (C) plots and (b) snow exclusion (SE) plots. DSP: deep snow period; ETP: early thawing period; MGS: middle in the growing season. ${ }^{*}$ indicated a significant difference among sampling dates for a same snow treatment. Figure S3. Wilcoxon rank-sum test bar plot for fungal phyla in the deep snow period (DSP), the early thawing period (ETP), and the middle in the growing season (MGS). C: Control; SE: snow exclusion. ${ }^{*}$ indicated a significant difference between snow regimes on a specific sampling date. Figure S4. One-way ANOVA test bar plot for fungal genus in (a) control (C) plots and (b) snow exclusion (SE) plots. DSP: deep snow period; ETP: early thawing period; MGS: middle in the growing season. ${ }^{*}$ indicated a significant difference among sampling dates for a same snow treatment. Figure S5. Wilcoxon rank-sum test bar plot for fungal genus in the deep snow period (DSP), the early thawing period (ETP), and the middle in the growing season (MGS). C: Control; SE: snow exclusion. * indicated a significant difference between snow regimes on a specific sampling date.

Additional file 2: Table S1. Sequencing results and number of observed and estimated OTUs at the species level (70\% $18 \mathrm{~S}$ identity). Table S2. Total and relative number of sequences and operational taxonomic units (OTUs) distributed to different fungal orders

\section{Acknowledgements}

We are grateful to the Long-term Research Station of Alpine Forest Ecosystems and the Collaborative Innovation Center of Ecological Security in the Upper Reaches of the Yangtze River.

\section{Authors' contributions}

LZ and YZR contributed equally to this work. BT, JZ and ZFX conceived the study. LZ, BT and LXW provided project support. KJY, ZJL, YL, HL, CMY and SNL performed the research and analyzed the data. LZ and YZR wrote the manuscript. LXW, RY and ZFX contributed to editing. All authors contributed to the work and gave final approval for publication.

\section{Funding}

The study was funded by the National Natural Science Foundation of China (Nos. 31700542, 32071745, 31870602, 31800519 and 31901295), Program of
Sichuan Excellent Youth Sci-Tech Foundation (No. 2020JDJQ0052) and the National Key Research and Development Program of China (Nos. 2016YFC0502505 and 2017YFC0505003).

\section{Availability of data and materials}

The datasets used and/or analysed during the current study are available from the corresponding author on reasonable request.

\section{Declarations}

Ethics approval and consent to participate

Not applicable.

\section{Consent for publication}

Not applicable.

\section{Competing interests}

The authors declare that they have no competing interests.

\section{Author details}

${ }^{1}$ Forestry Ecological Engineering in the Upper Reaches of the Yangtze River Key Laboratory of Sichuan Province \& National Forestry and Grassland Administration Key Laboratory of Forest Resources Conservation and Ecological Safety on the Upper Reaches of the Yangtze River \& Rainy Area of West China Plantation Ecosystem Permanent Scientific Research Base, Institute of Ecology \& Forestry, Sichuan Agricultural University, Chengdu 611130, China. ${ }^{2}$ Global Ecology Unit CREAF-CSIC-UAB, CSIC, 08193 Barcelona, Catalonia, Spain. ${ }^{3}$ Forschungszentrum Jülich GmbH, Agrosphere (IBG-3), Jülich, Germany. ${ }^{4}$ Helmholtz-Centre for Environmental Research-UFZ, Department of Community Ecology, Theodor-Lieser-Strasse 4, 06110 Halle (Saale), Germany.

Received: 5 August 2020 Accepted: 2 March 2021

Published online: 16 March 2021

\section{References}

Aanderud ZT, Jones SE, Schoolmaster DR Jr, Fierer N, Lennon JT (2013) Sensitivity of soil respiration and microbial communities to altered snowfall. Soil Biol Biochem 57:217-227. https://doi.org/10.1016/j.soilbio.2012.07.022

Allison SD, Jastrow JD (2006) Activities of extracellular enzymes in physically isolated fractions of restored grassland soils. Soil Biol Biochem 38:3245-3256. https://doi.org/10.1016/j.soilbio.2006.04.011

Antony R, Sanyal A, Kapse N, Dhakephalkar PK, Thamban M, Nair S (2016) Microbial communities associated with Antarctic snow pack and their biogeochemical implications. Microbiol Res 192:192-202. https://doi.org/10.1 016/j.micres.2016.07.004

Asemaninejad A, Thorn RG, Branfireun BA, Lindo Z (2018) Climate change favours specific fungal communities in boreal peatlands. Soil Biol Biochem 120:2836. https://doi.org/10.1016/j.soilbio.2018.01.029

Asemaninejad A, Thorn RG, Lindo Z (2017) Experimental climate change modifies degradative succession in boreal peatland fungal communities. Microb Ecol 73:521-531. https://doi.org/10.1007/s00248-016-0875-9

Bainard LD, Bainard JD, Hamel C, Gan Y (2014) Spatial and temporal structuring of arbuscular mycorrhizal communities is differentially influenced by abiotic factors and host crop in a semi-arid prairie agroecosystem. FEMS Microbiol Ecol 88:333-344. https://doi.org/10.1111/1574-6941.12300

Baldrian P (2017) Forest microbiome: diversity, complexity and dynamics. FEMS Microbiol Rev 41:109-130. https://doi.org/10.1093/femsre/fuw040

Barbeito I, Brücker RL, Rixen C, Bebi P (2013) Snow fungi-induced mortality of Pinus cembra at the alpine treeline: evidence from plantations. Arct Antarct Alp Res 45:455-470. https://doi.org/10.1657/1938-4246-45.4.455

Bardgett RD, Streeter TC, Cole L, Hartley IR (2002) Linkages between soil biota, nitrogen availability, and plant nitrogen uptake in a mountain ecosystem in the Scottish highlands. Appl Soil Ecol 19:121-134. https://doi.org/10.1016/ S0929-1393(01)00188-3

Borneman J, Hartin RJ (2000) PCR primers that amplify fungal rRNA genes from environmental samples. Appl Environ Microb 66:4356-4360. https://doi.org/1 0.1128/AEM.66.10.4356-4360.2000

Buckeridge KM, Banerjee S, Siciliano SD, Grogan P (2013) The seasonal pattern of soil microbial community structure in Mesic low arctic tundra. Soil Biol Biochem 65:338-347. https://doi.org/10.1016/j.soilbio.2013.06.012 
Chen H, Zhu Q, Peng C, Wu N, Wang Y, Fang X, Gao Y, Zhu D, Yang G, Tian J, Kang $X$, Piao $S$, Ouyang $H$, Xiang W, Luo Z, Jiang H, Song X, Zhang Y, Yu G, Zhao X, Gong P, Yao T, Wu J (2013) The impacts of climate change and human activities on biogeochemical cycles on the Qinghai-Tibetan plateau. Glob Chang Biol 19:2940-2955. https://doi.org/10.1111/gcb.12277

Chen Y-L, Deng Y, Ding J-Z, Hu H-W, Xu T-L, Li F, Yang G-B, Yang Y-H (2017a) Distinct microbial communities in the active and permafrost layers on the Tibetan plateau. Mol Ecol 26:6608-6620. https://doi.org/10.1111/mec.14396

Chen Y-L, Xu T-L, Veresoglou SD, Hu H-W, Hao Z-P, Hu Y-J, Liu L, Deng Y, Rillig MC, Chen B-D (2017b) Plant diversity represents the prevalent determinant of soil fungal community structure across temperate grasslands in northern China. Soil Biol Biochem 110:12-21. https://doi. org/10.1016/j.soilbio.2017.02.015

Cheng L, Zhang N, Yuan M, Xiao J, Qin Y, Deng Y, Tu Q, Xue K, Van Nostrand JD, Wu L, He Z, Zhou X, Leigh MB, Konstantinidis KT, Schuur EAG, Luo Q, Tiedje JM, Zhou J (2017) Warming enhances old organic carbon decomposition through altering functional microbial communities. ISME J 11:1825-1835. https://doi.org/10.1038/ismej.2017.48

Clemmensen KE, Bahr A, Ovaskainen O, Dahlberg A, Ekblad A, Wallander $\mathrm{H}$ Stenlid J, Finlay RD, Wardle DA, Lindahl BD (2013) Roots and associated fungi drive long-term carbon sequestration in boreal forest. Science 339:1615-1618. https://doi.org/10.1126/science.1231923

Corrales A, Turner BL, Tedersoo L, Anslan S, Dalling JW (2017) Nitrogen addition alters ectomycorrhizal fungal communities and soil enzyme activities in a tropical montane forest. Fungal Ecol 27:14-23. https://doi.org/10.1016/j. funeco.2017.02.004

Delgado-Baquerizo M, Bardgett RD, Vitousek PM, Mastre FT, Williams MA, Eldrdge DJ, Lamers H, Neuhauser S, Gallardo A, García-Velázquez L, Sala OE, Abades SR, Alfaro FD, Berhe AA, Bowker MA, Currier CM, Cutler NA, Hart SC, Hayes PE, Hseu Z-Y, Kirchmair M, Peña-Ramírez VM, Pérez CA, Reed SC, Santos F, Siebe C, Sullivan BW, Weber-Grullon L, Fierer N (2019) Changes in belowground biodiversity during ecosystem development. PNAS 116:6891-6896

Deng H, Pepin NC, Chen Y (2017) Changes of snowfall under warming in the Tibetan plateau. J Geophys Res-Atmos 122:7323-7341. https://doi.org/10.1 002/2017JD026524

Edgar RC, Haas BJ, Clemente JC, Quince C, Knight R (2011) UCHIME improves sensitivity and speed of chimera detection. Bioinformatics 27:2194-2200. https://doi.org/10.1093/bioinformatics/btr381

Fitzhugh RD, Driscoll CT, Groffman PM, Tierney GL, Fahey TJ, Hardy JP (2001) Effects of soil freezing disturbance on soil solution nitrogen, phosphorus, and carbon chemistry in a northern hardwood ecosystem. Biogeochemistry 56: 215-238. https://doi.org/10.1023/a:1013076609950

Frey SD, Knorr M, Parrent JL, Simpson RT (2004) Chronic nitrogen enrichment affects the structure and function of the soil microbial community in temperate hardwood and pine forests. Forest Ecol Manag 196:159-171. https://doi.org/10.1016/j.foreco.2004.03.018

Gao D, Hagedorn F, Zhang L, Liu J, Qu G, Sun J, Peng B, Fan Z, Zheng J, Jiang P, Bai E (2018) Small and transient response of winter soil respiration and microbial communities to altered snow depth in a midtemperate forest. Appl Soil Ecol 130:40-49. https://doi.org/10.1016/j.a psoil.2018.05.010

Gao Q, Yang ZL (2016) Diversity and distribution patterns of root-associated fungi on herbaceous plants in alpine meadows of southwestern China. Mycologia 108:281-291. https://doi.org/10.3852/14-324

Gobiet A, Kotlarski S, Beniston M, Heinrich G, Rajczak J, Stoffel M (2014) 21st century climate change in the European Alps - a review. Sci Total Environ 493:1138-1151. https://doi.org/10.1016/j.scitotenv.2013.07.050

Haei M, Rousk J, Ilstedt U, Öquist M, Bååth E, Laudon H (2011) Effects of soil frost on growth, composition and respiration of the soil microbial decomposer community. Soil Biol Biochem 43:2069-2077. https://doi.org/10.1016/j. soilbio.2011.06.005

Han Q, Huang J, Long D, Wang X, Liu J (2017) Diversity and community structure of ectomycorrhizal fungi associated with Larix chinensis across the alpine treeline ecotone of Taibai Mountain. Mycorrhiza 27:487-497. https://doi.org/1 $0.1007 / 500572-017-0766-z$

IUSS Working Group (2007) World reference base for soil resources 2006, first update 2007. World soil resources reports No. 103. FAO, Rome

Jusselme M-D, Saccone P, Zinger L, Faure M, Le Roux X, Guillaumaud N, Bernard L, Clement J-C, Poly F (2016) Variations in snow depth modify N-related soil microbial abundances and functioning during winter in subalpine grassland. Soil Biol Biochem 92:27-37. https://doi.org/10.1016/j.soilbio.2015.09.013

Kellner H, Zak DR, Vandenbol M (2010) Fungi unearthed: transcripts encoding lignocellulolytic and chitinolytic enzymes in forest soil. PLoS One 5:e10971. https://doi.org/10.1371/annotation/84b7b537-84f6-49e6-a c7c-9a2f0ad3f862

Kim CS, Nam JW, Jo JW, Kim SY, Han J-G, Hyun MW, Sung G-H, Han S-K (2016) Studies on seasonal dynamics of soil-higher fungal communities in Monglian oak-dominant Gwangneung forest in Korea. J Microbiol 54:14-22. https://doi. org/10.1007/s12275-016-5521-1

Kirk PM, Cannon PF, David JC, Stalpers JA (2001) Ainsworth and Bisby's dictionary of the fungi. CAB International, Wallingford, UK

Kivlin SN, Treseder KK (2014) Soil extracellular enzyme activities correspond with abiotic factors more than fungal community composition. Biogeochemistry 117:23-37. https://doi.org/10.1007/s10533-013-9852-2

Kreyling J, Haei M, Laudon H (2012) Absence of snow cover reduces understory plant cover and alters plant community composition in boreal forests. Oecologia 168:577-587. https://doi.org/10.1007/s00442-011-2092-Z

Li Z, Yang W, Yue K, Justine MF, He R, Yang K, Zhuang L, Wu F, Tan B, Zhang L, Xu Z (2017) Effects of snow absence on winter soil nitrogen dynamics in a subalpine spruce forest of southwestern China. Geoderma 307:107-113. https://doi.org/10.1016/j.geoderma.2017.08.003

Lindahl BD, Ihrmark K, Boberg J, Trumbore SE, Hogberg P, Stenlid J, Finlay RD (2007) Spatial separation of litter decomposition and mycorrhizal nitrogen uptake in a boreal forest. New Phytol 173:611-620. https://doi.org/10.1111/ j.1469-8137.2006.01936.x

Liu WX, Allison SD, Li P, Wang J, Chen DM, Wang ZH, Yang S, Diao LW, Wang B, Liu LL (2018) The effects of increased snow depth on plant and microbial biomass and community composition along a precipitation gradient in temperate steppes. Soil Boil Biochem 124:134-141. https://doi.org/10.1016/j. soilbio.2018.06.004

Männistö M, Vuosku J, Stark S, Saravesi K, Suokas M, Markkola A, Martz F, Rautio P (2018) Bacterial and fungal communities in boreal forest soil are insensitive to changes in snow cover conditions. FEMS Microbiol Ecol 94:fiy123. https:// doi.org/10.1093/femsec/fiy 123

Matzner E, Borken W (2008) Do freeze-thaw events enhance C and N losses from soils of different ecosystems? A review. Eur J Soil Sci 59:274-284. https://doi. org/10.1111/j.1365-2389.2007.00992.x

Morgado LN, Semenova TA, Welker JM, Walker MD, Smets E, Geml J (2016) Longterm increase in snow depth leads to compositional changes in arctic ecomycorrhizal fungal communities. Glob Chang Biol 22:3080-3096. https:// doi.org/10.1111/gcb.13294

Morrison EW, Frey SD, Sadowsky JJ, van Diepen LTA, Thomas WK, Pringle A (2016) Chronic nitrogen additions fundamentally restructure the soil fungal community in a temperate forest. Fungal Ecol 23:48-57. https://doi.org/10.1 016/j.funeco.2016.05.011

Mundra S, Halvorsen R, Kauserud H, Bahram M, Tedersoo L, Elberling B, Cooper EJ, Eidesen PB (2016) Ectomycorrhizal and saprotrophic fungi respond differently to long-term experimentally increased snow depth in the high Arctic. MicrobiologyOpen 5:856-869. https://doi.org/10.1002/mbo3.375

Oksanen J, Blanchet FG, Kindt R, Legendre R, Legendre P, Minchin PR, O'Hara RB, Simpson GL, Solymos P, Henry M, Wagner H (2013) Vegan: community ecology package. $R$ package version 2.0-10

Olofsson J, Ericson L, Torp M, Stark S, Baxter R (2011) Carbon balance of Arctic tundra under increased snow cover mediated by a plant pathogen. Nat Clim Chang 1:220-223. https://doi.org/10.1038/nclimate1142

Pardo LH, Fenn ME, Goodale CL, Geiser LH, Driscoll CT, Allen EB, Baron JS, Bobbink R, Bowman WD, Clark CM, Emmett B, Gilliam FS, Greaver TL, Hall SJ, Lilleskov EA, Liu L, Lynch JA, Nadelhoffer KJ, Perakis SS, Robin-Abbott MJ, Stoddard JL, Weathers KC, Dennis RL (2011) Effects of nitrogen deposition and empirical nitrogen critical loads for ecoregions of the United States. Ecol Appl 21:3049-3082. https://doi.org/10.1890/10-2341.1

R Development Core Team (2015) R: a language and environment for statistical computing. R Foundation for Statistical Computing, Vienna

Rane G, Gandhe RV (2006) Seasonal distribution of soil fungi from forest soils of Jalgaon District, Maharashtra. Zoos print J 21: 2407-2409. https://doi.org/1 0.11609/JoTT.ZPJ.1542.2407-9

Rosling A, Cox F, Cruz-Martinez K, Ihrmark K, Grelet G-A, Lindahl BD, Menkis A, James TY (2011) Archaeorhizomycetes: unearthing an ancient class of ubiquitous soil fungi. Science 333:876-879. https://doi.org/10.1126/science.1206958 
Rousk J, Bååth E, Brookes PC, Lauber CL, Lozupone C, Caporaso JG, Knight R, Fierer N (2010) Soil bacterial and fungal communities across a pH gradient in an arable soil. ISME J 4:1340-1351. https://doi.org/10.1038/ismej.2010.58

Santalahti M, Sun H, Jumpponen A, Pennanen T, Heinonsalo J (2016) Vertical and seasonal dynamics of fungal communities in boreal scots pine forest soil. FEMS Microbiol Ecol 92:fiw170. https://doi.org/10.1093/femsec/fiw170

Schadt CW, Martin AP, Lipson DA, Schmidt SK (2003) Seasonal dynamics of previously unknown fungal lineages in tundra soils. Science 301:1359-1361. https://doi.org/10.1126/science.1086940

Schloss PD, Westcott SL, Ryabin T, Hall JR, Hartmann M, Hollister EB, Lesniewski RA, Oakley BB, Parks DH, Robinson CJ, Sahl JW, Stres B, Thallinger GG, Van Horn DJ, Weber CF (2009) Introducing mothur: open-source, platformindependent, community-supported software for describing and comparing microbial communities. Appl Environ Micro 75:7537-7541. https://doi.org/1 0.1128/AEM.01541-09

Schneider T, Keiblinger KM, Schmid E, Sterflinger-Gleixner K, Ellersdorfer G, Roschitzki B, Richter A, Eberl L, Zechmeister-Boltenstern S, Riedel K (2012) Who is who in litter decomposition? Metaproteomics reveals major microbial players and their biogeochemical functions. ISME J 6:1749-1762. https://doi. org/10.1038/ismej.2012.11

Semenova TA, Morgado LN, Welker JM, Walker MD, Smets E, Geml J (2016) Compositional and functional shifts in arctic fungal communities in response to experimentally increased snow depth. Soil Biol Biochem 100:201-209. https://doi.org/10.1016/j.soilbio.2016.06.001

Shahzad T, Chenu C, Genet P, Barot S, Perveen N, Mougin C, Fontaine S (2015) Contribution of exudates, arbuscular mycorrhizal fungi and litter depositions to the rhizosphere priming effect induced by grassland species. Soil Biol Biochem 80:146-155. https://doi.org/10.1016/j.soilbio.2014.09.023

Shi L-L, Mortimer PE, Slik JWF, Zou X-M, Xu J, Feng W-T, Qiao L (2014) Variation in forest soil fungal diversity along a latitudinal gradient. Fungal Divers 64: 305-315. https://doi.org/10.1007/s13225-013-0270-5

Solly EF, Lindahl BD, Dawes MA, Peter M, Souza RC, Rixen C, Hagedorn F (2017) Experimental soil warming shifts the fungal community composition at the alpine treeline. New Phytol 215:766-778. https://doi.org/10.1111/nph.14603

Song Y, Zou Y, Wang G, Yu X (2017) Altered soil carbon and nitrogen cycles due to the freeze-thaw effect: a meta-analysis. Soil Biol Biochem 109:35-49. https://doi.org/10.1016/j.soilbio.2017.01.020

Sorensen PO, Beller HR, Bill M, Bouskill NJ, Hubbard SS, Karaoz U, Polussa A Steltzer H, Wang S, Williams KH, Wu Y, Brodie EL (2020) The snowmelt niche differentiates three microbial life strategies that influence soil nitrogen availability during and after winter. Front Microbiol 11:871. https://doi.org/1 0.3389/fmicb.2020.00871

Sorensen PO, Templer PH, Finzi AC (2016) Contrasting effects of winter snowpack and soil frost on growing season microbial biomass and enzyme activity in two mixed-hardwood forests. Biogeochemistry 128:141-154. https://doi.org/1 0.1007/s10533-016-0199-3

Stres B, Philippot L, Faganeli J, Tiedje JM (2010) Frequent freeze-thaw cycles yield diminished yet resistant and responsive microbial communities in two temperate soils: a laboratory experiment. FEMS Microbiol Ecol 74:323-335. https://doi.org/10.1111/j.1574-6941.2010.00951.x

Vance ED, Brookes PC, Jenkinson DS (1987) An extraction method for measuring soil microbial biomass C. Soil Biol Biochem 19:703-707. https://doi.org/10.101 6/0038-0717(87)90052-6

Vořišková J, Brabcová V, Cajthaml T, Baldrian P (2014) Seasonal dynamics of fungal communities in a temperate oak forest soil. New Phytol 201:269-278. https://doi.org/10.1111/nph.12481

Wang J, Zhang M, Wang S, Ren Z, Che Y, Qiang F, Qu D (2016) Decrease in snowfall/rainfall ratio in the Tibetan plateau from 1961 to 2013. J Geogr Sci 26:1277-1288. https://doi.org/10.1007/s11442-016-1326-8

Wang L-F, Cai Y-J, Xie H-T (2007) Relationships of soil physical and microbial properties with nitrous oxide emission under effects of freezing-thawing cycles. Chin J Appl Ecol 18:2361-2366 18163324 (in Chinese)

Wipf S, Rixen C (2010) A review of snow manipulation experiments in Arctic and alpine tundra ecosystems. Polar Res 29:95-109. https://doi.org/10.3402/polar. V29i1.6054

Wubs ERJ, Woodin SJ, Stutter MI, Wipf S, Sommerkorn M, van der Wal R (2018) Two decades of altered snow cover does not affect soil microbial ability to catabolize carbon compounds in an oceanic alpine heath. Soil Biol Biochem 124:101-104. https://doi.org/10.1016/j.soilbio.2018.05.034

Xu Z-F, Hu R, Xiong P, Wan C, Cao G, Liu Q (2010) Initial soil responses to experimental warming in two contrasting forest ecosystems, eastern
Tibetan plateau, China: nutrient availabilities, microbial properties and enzyme activities. Appl Soil Ecol 46:291-299. https://doi.org/10.1016/j.a psoil.2010.07.005

Yang K, Peng C, Peñuelas J, Kardol P, Li Z, Zhang L, Ni X, Yue K, Tan B, Yin R, Xu $Z$ (2019) Immediate and carry-over effects of increased soil frost on soil respiration and microbial activity in a spruce forest. Soil Biol Biochem 135:51-59. https://doi.org/10.1016/j.soilbio.2019.04.012

Yang ZL (2000) Species diversity of the genus Amanita (Basidiomycetes) in China. Acta Bot Yunn 22:135-142. https://doi.org/10.3969/j.issn.2095-084 5.2000.02.004. (in Chinese)

Yao F, Vik U, Brysting AK, Carlsen T, Halvorsen R, Kauserud H (2013) Substantial compositional turnover of fungal communities in an alpine ridge-to-snowbed gradient. Mol Ecol 22:5040-5052. https://doi.org/10.1111/mec.12437

Zhang YD, Gu FX, Liu SR, Liu YC, Li C (2013) Variations of carbon stock with forest types in subalpine region of southwestern China. Forest Ecol Manag 300:88-95. https://doi.org/10.1016/j.foreco.2012.06.010

Zinger L, Shahnavaz B, Baptist F, Geremia RA, Choler P (2009) Microbial diversity in alpine tundra soils correlates with snow cover dynamics. ISME J 3:850-859. https://doi.org/10.1038/ismej.2009.20

\section{Submit your manuscript to a SpringerOpen ${ }^{\circ}$ journal and benefit from:}

- Convenient online submission

- Rigorous peer review

- Open access: articles freely available online

- High visibility within the field

- Retaining the copyright to your article

Submit your next manuscript at $\boldsymbol{\nabla}$ springeropen.com 